\title{
Bioremediation of soil contaminated with spent and fresh cutting fluids by Pleurotus pulmonarius (Fries) Quelet
}

\author{
Clementina O. Adenipekun $^{1 \star}$, A. R. Ipeaiyeda ${ }^{2}$ and A. J. Olayonwa ${ }^{1}$ \\ ${ }^{1}$ Department of Botany, University of Ibadan, Nigeria. \\ ${ }^{2}$ Department of Chemistry, University of Ibadan, Nigeria.
}

Accepted 30 August, 2013

\begin{abstract}
Contamination of soil with industrial cutting fluids containing heavy metals and petroleum hydrocarbons has detrimental effects on ecosystems. As such contaminants constitute risk to human health; they can enter the food chain through agricultural products or contaminated drinking water. This growing concern about contamination with cutting fluids makes remediation process imperative. White rot fungus, Pleurotus pulmonarius was investigated in this pilot study for its potential to bioremediate contaminants such as heavy metals and total petroleum hydrocarbon at 10,20 and $30 \%$ contamination levels. Control experiment ( $0 \%$ contamination level) was also set up. The effects of incubation periods on the contents of cutting fluid contaminated soil inoculated with $P$. pulmonarius after two months was equally studied. Bioremediation efficiently occurred at $10 \%$ contamination level. At this level, soil pH was 6.9 and organic carbon, organic matter and phosphate contents increased by 22.4, 21.4 and $3.5 \%$, respectively for spent cutting fluid and by $30.0,30.1$ and $50.0 \%$ for fresh cutting fluid respectively after two months of incubation with the fungus. Copper, manganese and nickel decreased significantly by $35.3,25.0$ and $1.5 \%$, respectively for spent cutting fluid contaminated soil and by $\mathbf{1 0 . 5}, 54.4$ and $\mathbf{5 5 . 9} \%$ respectively for fresh cutting fluid contaminated soil. High percentage degradation of Total Petroleum Hydrocarbon (TPH) at $10 \%$ contamination level was about $90.0 \%$ for both fresh and spent contaminated soil samples. The cation exchange capacity increased by 50.8 and $38.4 \%$ for spent and fresh cutting fluid contaminated soil samples respectively. These results indicate the efficiency of $P$. pulmonarius as a bioremediating agent of heavy metals and TPH in contaminated soil.
\end{abstract}

Key words: Bioremediation, cutting fluids, total petroleum hydrocarbon, cation-exchange analysis, heavy metals.

\section{INTRODUCTION}

Cutting fluids are used in the engineering industry to improve machine tools performance and productivity. They are generally composed of oil and organic compounds mixed with water. Once the mixture has been used for a period of time, it degrades and generates a toxic fluid as waste (Bio-wise, 2001). The fluid includes chemicals that inhibit metal corrosion and microbial activities (biocides) while lubricating and cooling the metal cutting process (Van der Gast et al., 2002). Cutting fluids are difficult to degrade due to the presence of emulsified oil and their high molecular weight components. Different methods have been used to treat cutting fluids. One of 
the methods involves coagulation with chemical solutions and is applicable only to emulsified oil. Another method is membrane separation in which case fouling of membrane element leads to huge reduction in efficiency. The unavailability of chemical and fouling problem makes the disposal cost rise. The rising disposal costs make it a financial burden on industry, thus resulting in disposal of partially treated cutting fluid on soil. There is therefore a clear need to develop a cost effective and reliable system for treating cutting fluids.

The major mechanism for eliminating spilled oil from the environment is the microbial degradation (Atlas, 1995). This remediation option which involves the use of microorganisms to detoxify or remove organic and inorganic compounds from the environment also offers green technology solution to the problem of environmental degradation. The technological process relied upon microbial enzymatic activities to transform or degrade the contaminants from the environments (Phillip and Atlas, 2005). It is a form of bioremediation that harness fungal mycelium to transform complex or simple chemical compounds into non-hazardous forms thereby resulting in materials of higher nutritive value or simply reducing the final bulk of the product (Grady, 1985). Fungi use is expected to be relatively cheap as they can be cultivated on a number of inexpensive agricultural or forest wastes such as corncobs and sawdust (Lavrovsky, 2004). The natural degradative ability of white rot fungi can be used in the decontamination of polluted soil by ramifying the substratum and digesting it through the secretion of extracellular enzymes which are non specific. The extracellular lignin-degrading enzymes such as manganese peroxidase, laccase and lignin peroxidase can be secreted by white rot fungi to decontaminated polluted soil (Croan, 2000). Okparanma et al. (2011) stated that spent white-rot fungi (Pleurotus ostreatus) substrate can be used to biotreat Nigerian oil-based drill cuttings containing Polyaromatic Hydrocarbons (PAH's) under laboratory conditions. Adenipekun (2008) reported an improvement in the nutrient contents of the soil, bioaccumulation of heavy metals, degradation of total petroleum hydrocarbon (TPH), lignin, and increased activity of polyphenol oxidase and peroxidase due to biodegradation of spent cutting fluids by Pleurotus tuberregium.

The most important processes in soil are regarded as ion-exchange, acidification and salinization, oxidationreduction reactions and metal-organic matter interactions. Ion exchange reaction is important in soil because it controls both the retention of added fertilizer elements and soils capacity to resist changes imposed by the addition of extraneous materials. The ease with which cations are adsorbed or released from soil particle surfaces depends to a large extent on the nature of the exchange cation. Therefore, cation exchange capacity measures the ability of the soil to hold cations at the negative sites by electrostatic force. It has close association with $\mathrm{pH}$ and and soil particle surfaces. The concept of soil $\mathrm{pH}$ and specific adsorption of cation are important agriculturally. The aim of this study was to remediate cutting fluid contaminated soil with Pleurotus pulmonarius in which process, the extent of depletion of soil nutrient content, the extent of accumulation of toxic metals and total petroleum hydrocarbon by the fungus and cation exchange capacity of the soil were investigated.

\section{MATERIALS AND METHODS}

\section{Sample and fungus collection}

Top soil sample used for this experiment was collected within 1 to $10 \mathrm{~cm}$ depth from the nursery site of the Department of Botany, University of lbadan. The soil was sieved to $2 \mathrm{~mm}$ to remove debris. Pure cultures of $P$. pulmonarius was collected from Plant physiology unit of the same Department. Pure spawns of this fungus was prepared according to the method used by Jonathan and Fasidi (2001). Freshly harvested rice straw was collected from International Institute of Tropical Agriculture (IITA), Ibadan and air-dried in the laboratory for seven days to remove moisture content. The dried rice straw was cut into 0.1 to $3 \mathrm{~mm}$ size using guillotine. Wheat bran was bought at the feed mill of the popular Bodija Market in Ibadan. Fresh and spent cutting fluid was obtained from the workshop unit in the Departments of Physics and Mechanical Engineering, University of Ibadan. The fluid is suitable for metal working as admixture or emulsion with water.

\section{Pure spawn preparation}

The spawn of the fungus was prepared according to the method of Jonathan and Fasidi (2001). Rice straw was soaked in water for $1 \mathrm{~h}$ and then sieved until no more water oozed out. Wheat bran was added as an additive to rice straw contained in a $350 \mathrm{ml}$ sterile bottles covered with aluminium foil and autoclaved at $121^{\circ} \mathrm{C}$ for 15 min. After cooling, the bottles were inoculated with pure cultures of $P$. pulmonarius. All bottles were incubated at $28^{\circ} \mathrm{C}$ for 2 weeks until the substrate was completely ramified.

\section{Experimental setup for culture conditions}

The culture conditions were prepared according to the method of Adenipekun and Fasidi (2005). $400 \mathrm{~g}$ of soil were weighed into the $350 \mathrm{~cm}^{2}$ sterile bottles and then mixed thoroughly with $25 \mathrm{ml}$ of water soluble cutting fluid of varying concentrations $(0,10,20$ and $30 \%)$. A mud balance was used in measuring the weight percent volume as density $(\mathrm{g} / \mathrm{ml})$ of the fluid. $80 \mathrm{~g}$ of moistened rice straw added was laid on the contaminated soil in each bottle separated with a wire gauze and covered with aluminium foil. The bottles were then autoclaved at a temperature of $121^{\circ} \mathrm{C}$ temperature for $20 \mathrm{~min}$. After cooling, each bottle was inoculated with $10 \mathrm{~g}$ of vigorously grown spawn of $P$. pulmonarius. The bottles were incubated at room temperature for two months in an incubator. In the first set of control treatment, cutting fluid was not added to the soil while in the second set different percentages of cutting fluid were added to the soil and not inoculated with the fungus. At the end of the period of incubation, the mycelium ramified substrate was carefully separated from the soil layer ensuring that soil particles did not mix with it.

The different treatments were replicated three times and incubated at $28 \pm 2^{\circ} \mathrm{C}$ in the dark for 60 days. The contaminated soil samples were analyzed for the physicochemical parameters after drying. 
Table 1. Nutrient contents of spent cutting-fluid contaminated soil incubated with $P$. pulmonarius for 2 months.

\begin{tabular}{|c|c|c|c|c|c|c|c|}
\hline $\begin{array}{c}\text { Level of } \\
\text { contamination (\%) }\end{array}$ & $\begin{array}{l}\text { Incubation period } \\
\text { (month) }\end{array}$ & $\begin{array}{l}\text { Organic } \\
\text { carbon (\%) }\end{array}$ & $\begin{array}{c}\text { Organic } \\
\text { matter (\%) }\end{array}$ & $\begin{array}{l}\text { Total nitrogen } \\
(\mathrm{mg} / \mathrm{kg})\end{array}$ & $\begin{array}{c}\text { Phosphorus } \\
\text { (mg/kg) }\end{array}$ & $\begin{array}{l}\text { Potassium } \\
(\mathrm{mg} / \mathrm{kg})\end{array}$ & $\mathrm{pH}$ \\
\hline \multirow{2}{*}{ Control $(0)$} & 0 & $1.96^{b}$ & $3.38^{\mathrm{b}}$ & $98.0^{a}$ & $11.8^{b}$ & $146^{\mathrm{b}}$ & $7.0^{\mathrm{a}}$ \\
\hline & 2 & $2.32^{\mathrm{a}}$ & $3.66^{a}$ & $98.0^{a}$ & $12.9^{\mathrm{a}}$ & $160^{\mathrm{a}}$ & $6.8^{\mathrm{a}}$ \\
\hline \multirow{2}{*}{10} & 0 & $2.55^{\mathrm{b}}$ & $4.40^{\mathrm{b}}$ & $12.4^{\mathrm{a}}$ & $14.3^{\mathrm{a}}$ & $239^{\mathrm{a}}$ & $6.9^{\mathrm{a}}$ \\
\hline & 2 & $3.12^{\mathrm{a}}$ & $5.34^{\mathrm{a}}$ & $10.9^{b}$ & $14.8^{\mathrm{a}}$ & $341^{b}$ & $6.9^{\mathrm{a}}$ \\
\hline \multirow{2}{*}{20} & 0 & $2.26^{\mathrm{a}}$ & $3.90^{\mathrm{a}}$ & $11.8^{\mathrm{a}}$ & $16.2^{\mathrm{a}}$ & $343^{a}$ & $6.9^{\mathrm{a}}$ \\
\hline & 2 & $2.65^{b}$ & $4.27^{\mathrm{a}}$ & $10.8^{\mathrm{a}}$ & $18.0^{\mathrm{a}}$ & $395^{\mathrm{a}}$ & $6.8^{\mathrm{a}}$ \\
\hline \multirow{2}{*}{30} & 0 & $2.92^{\mathrm{a}}$ & $5.52^{\mathrm{a}}$ & $14.8^{\mathrm{a}}$ & $17.5^{\mathrm{a}}$ & $176^{\mathrm{a}}$ & $7.0^{\mathrm{a}}$ \\
\hline & 2 & $3.20^{\mathrm{a}}$ & $5.03^{\mathrm{a}}$ & $14.4^{b}$ & $17.6^{\mathrm{a}}$ & $266^{\mathrm{a}}$ & $6.7^{\mathrm{a}}$ \\
\hline
\end{tabular}

Each value is a mean of three replicates. Values in the same column with different letters are significantly different $(P \leq 0.05)$.

Table 2. Nutrient contents of fresh cutting fluid contaminated soil incubated with $P$. pulmonarius for 2 months.

\begin{tabular}{|c|c|c|c|c|c|c|c|}
\hline $\begin{array}{c}\text { Level of } \\
\text { contamination } \\
(\%)\end{array}$ & $\begin{array}{c}\text { Incubation } \\
\text { period } \\
\text { (month) }\end{array}$ & $\begin{array}{c}\text { Organic } \\
\text { carbon (\%) }\end{array}$ & $\begin{array}{c}\text { Organic } \\
\text { matter (\%) }\end{array}$ & $\begin{array}{l}\text { Total nitrogen } \\
(\mathrm{mg} / \mathrm{kg})\end{array}$ & $\begin{array}{l}\text { Phosphorus } \\
\text { (mg/kg) }\end{array}$ & $\begin{array}{c}\text { Potassium } \\
(\mathrm{mg} / \mathrm{kg})\end{array}$ & $\mathrm{pH}$ \\
\hline \multirow{2}{*}{ Control (0) } & 0 & $2.60^{a}$ & $4.49^{\mathrm{a}}$ & $13.7^{\mathrm{a}}$ & $13.7^{\mathrm{a}}$ & $179^{a}$ & $6.5^{\mathrm{a}}$ \\
\hline & 2 & $3.18^{\mathrm{a}}$ & $5.48^{\mathrm{a}}$ & $13.5^{\mathrm{a}}$ & $14.8^{\mathrm{a}}$ & $292^{b}$ & $6.5^{\mathrm{a}}$ \\
\hline \multirow{2}{*}{10} & 0 & $2.43^{\mathrm{b}}$ & $4.18^{\mathrm{b}}$ & $10.9^{\mathrm{a}}$ & $16.7^{\mathrm{a}}$ & $171^{b}$ & $6.6^{\mathrm{a}}$ \\
\hline & 2 & $3.16^{\mathrm{a}}$ & $5.44^{\mathrm{a}}$ & $12.3^{b}$ & $17.2^{\mathrm{b}}$ & $297^{\mathrm{a}}$ & $6.9^{\mathrm{a}}$ \\
\hline \multirow{2}{*}{20} & 0 & $2.15^{\mathrm{b}}$ & $4.13^{\mathrm{a}}$ & $11.8^{\mathrm{a}}$ & $14.9^{\mathrm{a}}$ & $343^{a}$ & $6.7^{b}$ \\
\hline & 2 & $2.40^{\mathrm{a}}$ & $3.70^{\mathrm{a}}$ & $10.8^{\mathrm{a}}$ & $16.6^{\mathrm{a}}$ & $304^{a}$ & $6.9^{\mathrm{a}}$ \\
\hline \multirow{2}{*}{30} & 0 & $2.55^{\mathrm{a}}$ & $4.39^{b}$ & $14.8^{\mathrm{a}}$ & $17.4^{\mathrm{a}}$ & $312^{a}$ & $6.6^{\mathrm{a}}$ \\
\hline & 2 & $2.95^{\mathrm{b}}$ & $5.09^{\mathrm{a}}$ & $14.4^{\mathrm{b}}$ & $17.6^{\mathrm{a}}$ & $331^{a}$ & $6.9^{b}$ \\
\hline
\end{tabular}

Each value is a mean of three replicates. Values in the same column with different letters are significantly different $(P \leq 0.05)$.

\section{Physicochemical analysis of soil}

The $\mathrm{pH}$ was determined for all the air-dried soil samples in soil water (1:1) suspension using a Jenway $3510 \mathrm{pH}$ meter according to a method adapted by MAFF (1986). Total organic carbon in soil was determined by oxidation with excess amount of potassium dichromate and the unreacted potassium dichromate titrated with standard ferrous sulphate. Total nitrogen was determined by the kjeldhal method. Ascorbic acid and flame photometry methods were adopted for the determination of phosphorus and potassium respectively according to the official methods of analysis (AOAC, 2003). The exchangeable cations of the soil were extracted with ammonium acetate solution and the 'cation exchange capacity' was measured by the methods outlined by Sparks et al. (1996). Total petroleum hydrocarbon (TPH) was determined using the method of the Inter-governmental Oceanographic Commission (IOC) adapted by Onianwa and Essien (1999). The concentrations of toxic metals $(\mathrm{Mn}, \mathrm{Pb}, \mathrm{Ni}, \mathrm{Cu})$ in soil samples were determined by atomic absorption spectrophotometry after digestion with aqua regia. Reagent blanks were used to estimate analytical bias. Test for significant differences between metal concentrations, nutrient contents and exchangeable fractions at different incubation periods were carried out using ANOVA.

\section{RESULTS}

Tables 1 and 2 show the nutrient contents of spent and fresh cutting-fluid contaminated soil samples incubated respectively with $P$. pulmonarius. After two months of incubation, the control experiment revealed an increase in organic carbon contents, organic matter, phosphorus content and potassium. The same trend of increase in contents of these parameters was observed after two months for 10,20 and $30 \%$ of contamination with respective spent and fresh cutting fluids. There was a slight reduction in soil $\mathrm{pH}$ but the difference was not significant $(\mathrm{P} \leq 0.05)$ upon treatment with $P$. pulmonarius for all the levels of contamination. The difference was significant at 0,10 and $20 \%$ for organic carbon, organic matter and potassium. The levels of organic carbon, organic matter, 
Table 3. Heavy metal contents $(\mathrm{mg} / \mathrm{kg})$ of spent cutting fluid contaminated soil incubated with $P$. pulmonarius for 2 months.

\begin{tabular}{cccccc}
\hline Level of contamination (\%) & Incubation period (month) & $\mathbf{M n}$ & $\mathbf{P b}$ & $\mathbf{N i}$ & $\mathbf{C u}$ \\
\hline \multirow{2}{*}{ Control (0) } & 0 & $0.066^{\mathrm{a}}$ & $0.047^{\mathrm{a}}$ & $0.055^{\mathrm{a}}$ & $0.021^{\mathrm{a}}$ \\
& 2 & $0.061^{\mathrm{b}}$ & $0.044^{\mathrm{a}}$ & $0.055^{\mathrm{a}}$ & $0.017^{\mathrm{b}}$ \\
\multirow{2}{*}{10} & 0 & & & & \\
& 2 & $0.072^{\mathrm{a}}$ & $0.022^{\mathrm{a}}$ & $0.065^{\mathrm{a}}$ & $0.034^{\mathrm{a}}$ \\
\multirow{2}{*}{20} & 0 & $0.054^{\mathrm{b}}$ & $0.055^{\mathrm{a}}$ & $0.064^{\mathrm{a}}$ & $0.022^{\mathrm{a}}$ \\
& 2 & & & & \\
& & $0.060^{\mathrm{a}}$ & $0.042^{\mathrm{a}}$ & $0.053^{\mathrm{a}}$ & $0.037^{\mathrm{a}}$ \\
\multirow{2}{*}{30} & $0.064^{\mathrm{a}}$ & $0.042^{\mathrm{a}}$ & $0.049^{\mathrm{a}}$ & $0.027^{\mathrm{b}}$ \\
& 2 & & & & \\
& $0.066^{\mathrm{a}}$ & $0.036^{\mathrm{a}}$ & $0.025^{\mathrm{a}}$ & $0.039^{\mathrm{a}}$ \\
& 2 & $0.031^{\mathrm{b}}$ & $0.036^{\mathrm{a}}$ & $0.064^{\mathrm{b}}$ & $0.032^{\mathrm{b}}$ \\
\hline
\end{tabular}

Each value is a mean of three replicates. Values in the same column with different letters are significantly different $(P \leq 0.05)$.

Table 4. Heavy metal contents $(\mathrm{mg} / \mathrm{kg})$ in the fresh cutting fluid contaminated soil incubated with P. pulmonarius for 2 months.

\begin{tabular}{cccccc}
\hline Level of contamination (\%) & Incubation period (month) & $\mathbf{M n}$ & $\mathbf{P b}$ & $\mathbf{N i}$ & $\mathbf{C u}$ \\
\hline \multirow{2}{*}{ Control (0) } & 0 & $0.044^{\mathrm{a}}$ & $0.021^{\mathrm{a}}$ & $0.036^{\mathrm{a}}$ & $0.029^{\mathrm{a}}$ \\
& 2 & $0.034^{\mathrm{b}}$ & $0.023^{\mathrm{a}}$ & $0.034^{\mathrm{a}}$ & $0.023^{\mathrm{b}}$ \\
\multirow{2}{*}{10} & 0 & $0.057^{\mathrm{a}}$ & $0.009^{\mathrm{a}}$ & $0.059^{\mathrm{a}}$ & $0.019^{\mathrm{a}}$ \\
& 2 & $0.026^{\mathrm{b}}$ & $0.018^{\mathrm{a}}$ & $0.026^{\mathrm{b}}$ & $0.017^{\mathrm{b}}$ \\
\multirow{2}{*}{20} & 0 & & & & \\
& 2 & $0.065^{\mathrm{a}}$ & $0.024^{\mathrm{a}}$ & $0.064^{\mathrm{a}}$ & $0.025^{\mathrm{a}}$ \\
\multirow{2}{*}{30} & 0 & $0.064^{\mathrm{a}}$ & $0.024^{\mathrm{a}}$ & $0.063^{\mathrm{a}}$ & $0.021^{\mathrm{b}}$ \\
& 2 & $0.065^{\mathrm{a}}$ & $0.035^{\mathrm{a}}$ & $0.051^{\mathrm{a}}$ & $0.033^{\mathrm{a}}$ \\
\hline
\end{tabular}

Each value is a mean of three replicates. Values in the same column with different letters are significantly different $(P \leq 0.05)$.

phosphorus and potassium after three months were found to be significantly different from the initial levels for only $10 \%$ of contamination. This pattern was observed for both cutting and fresh fluids (Tables 1 and 2). Heavy metals contents in spent and fresh cutting fluid polluted soil samples incubated respectively with $P$. pulmonarius were shown in Tables 3 and 4. Reduction in $\mathrm{Mn}, \mathrm{Ni}, \mathrm{Cu}$ levels were observed after two months of incubation at 10,20 and $30 \%$ contamination of the soil with spent and fresh cutting fluid respectively. The reduction in metal levels was also noticed with the control sample for these metals.

The reduction for $\mathrm{Mn}, \mathrm{Ni}$ and $\mathrm{Cu}$ at all levels of contamination was found to be significant at $P \leq 0.05$. There was a slight reduction in lead concentrations from 0.047 to $0.044 \mathrm{mg} / \mathrm{kg}$ for the control sample while the concentrations remained constant for other levels $(10,20$ and $30 \%$ ) of contamination. There was removal of total petroleum hydrocarbons (TPH) from spent and fresh cutting fluid contaminated soil samples as shown in Figures 1 and 2. TPH loss decreases as the concentration of cutting fluid increases. The highest level of degradation was obtained at $10 \%$ level of contamination while the least degradation was obtained at $30 \%$ level of contamination. Table 5 shows the cation exchange capacity (CEC), which is a useful indicator of soil fertility. The more the value of cation exchange capacity, the better the fertility. The increase in CEC values at $10 \%$ level of contamination with both spent and fresh cutting fluid was to be significant from each other at $\mathrm{P} \leq 0.05$.

\section{DISCUSSION}

The use of fungi in the remediation of polluted soil was preferred to bacteria because the former have the lignin degrading systems which act extracellularly (Barr and Aust, 1994). Strains like Pleurotus spp seem to be more suitable for application in soil remediation; although, they can also produce their characteristic ligninolytic enzymes 


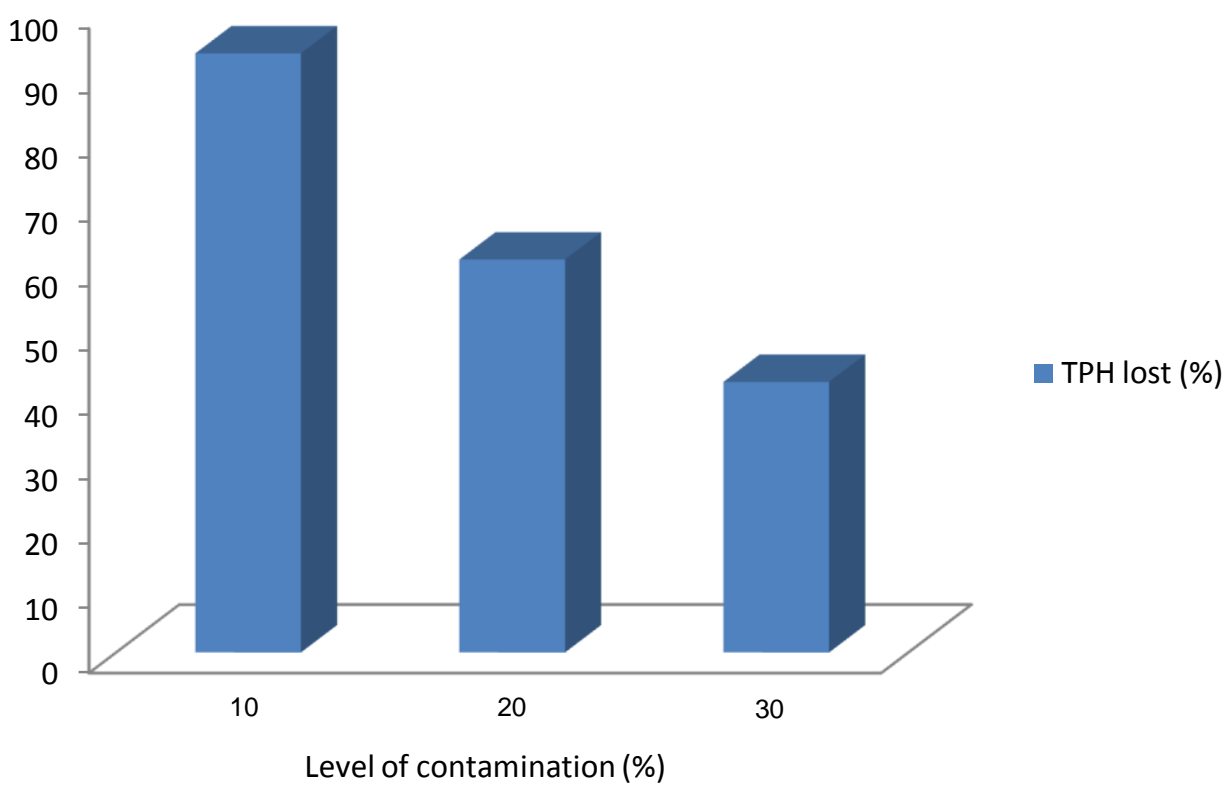

Figure 1. Loss of TPH (\%) of the spent cutting fluid contaminated soils incubated with $P$. pulmonarius for 2 months.

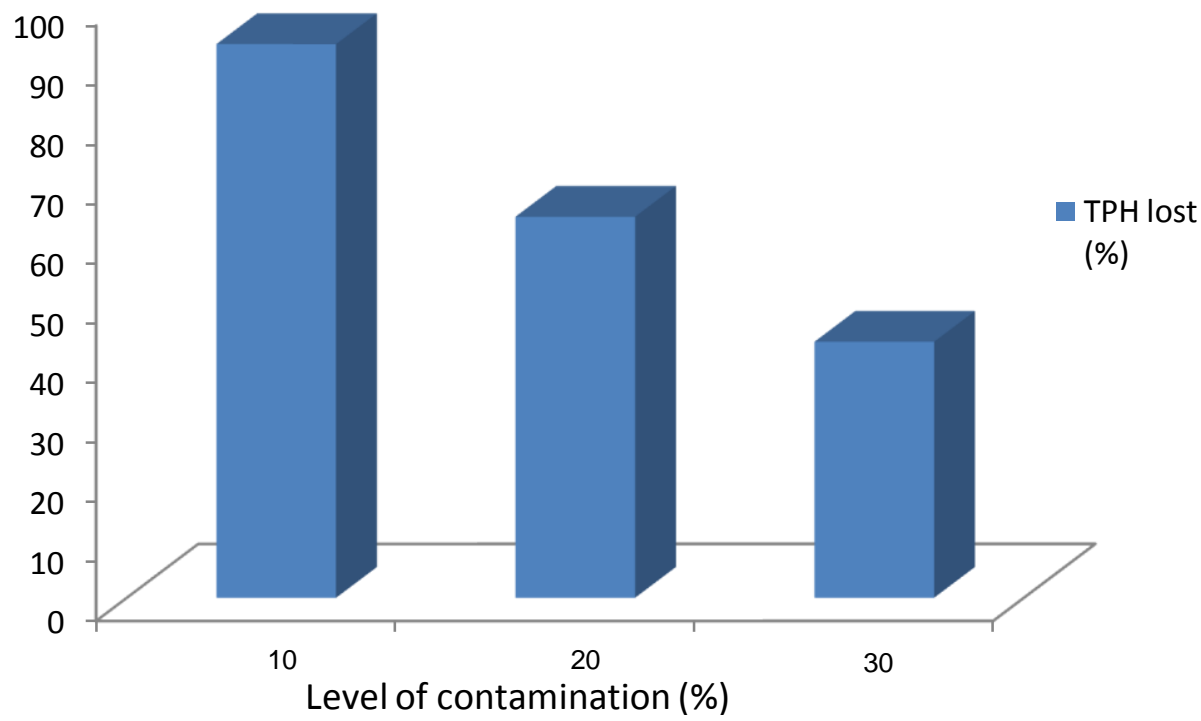

Figure 2. Loss of TPH (\%) of the fresh cutting fluid contaminated soils incubated with $P$. pulmonarius for 2 months.

Table 5. Results of cation exchange capacity (meq/100 g) at different levels of contamination with spent and fresh cutting fluids.

\begin{tabular}{cccccc}
\hline \multicolumn{2}{c}{ Spent cutting fluid } & \multicolumn{3}{c}{ Fresh cutting fluid } \\
\hline Cutting fluid concentration (\%) & 0 month & 2 months & Cutting fluid concentration (\%) & 0 month & 2 months \\
\hline Control (0) & $3.96^{\mathrm{a}}$ & $6.11^{\mathrm{a}}$ & Control (0) & $3.96^{\mathrm{a}}$ & $6.21^{\mathrm{a}}$ \\
10 & $7.30^{\mathrm{a}}$ & $11.0^{\mathrm{b}}$ & 10 & $7.30^{\mathrm{a}}$ & $10.1^{\mathrm{b}}$ \\
20 & $8.12^{\mathrm{a}}$ & $7.94^{\mathrm{a}}$ & 20 & $8.43^{\mathrm{a}}$ & $8.32^{\mathrm{a}}$ \\
30 & $8.62^{\mathrm{a}}$ & $8.35^{\mathrm{a}}$ & 30 & $8.83^{\mathrm{a}}$ & $8.47^{\mathrm{a}}$ \\
\hline
\end{tabular}

Each value is a mean of three replicates. Values in the same column with different letters as superscript are significantly different $(P \leq 0.05)$. 
in the soil environment (Kubatova et al., 2001; Lang et al., 1998). In this study, the organic matter and organic carbon were found to be higher in fresh cutting fluid than in spent cutting fluid. This is expected as fresh cutting fluid contains more carbon and phenolic compounds than the spent one (Van der Gast et al., 2002). The high organic matter in fresh cutting fluid arising from greater percentage of phenolic compounds will stimulate the fungus to secrete more enzymes than in spent fluid. The reduction in total nitrogen levels at different levels of contamination except at $10 \%$ level for fresh cutting fluid contamination soil suggests that the fungus must have utilized nitrogen for growth during the incubation period. This is in agreement with the findings of Benka-Coker and Ekundayo (1995) who reported low levels of nitrogen and phosphorus from a crude oil spill site in the Niger Delta of Nigeria. In this study, the $\mathrm{pH}$ of the soil which ranges from 6.7 to 7.0 also influenced the occurrence of biotransformation process of cutting fluid contaminated soil. This agrees with the findings of Bishnoi et al. (2008) who reported that optimum $\mathrm{pH} 7.0$ support biodegradetion of polycyclic aromatic hydrocarbons by Phanerochaete chrysosporium in sterile and unsterile soil.

The reduction in the heavy metals contents of both contaminated and control soil samples, after 2 months of incubation with $P$. pulmonarius indicates the accumulation of heavy metals such as $\mathrm{Cu}, \mathrm{Mn}$ and $\mathrm{Ni}$ from the soil by the fungus. The fact that the salts of these metals are soluble and are assimilated by microbes, this finding could be related. Fungi have ability to accumulate metals from the environment and have found relevance in the treatment of heavy metals containing effluent (Siegel et al., 1990; Kalac et al., 1996). The TPH loss decreased as the level of contamination increased suggesting the presence of low petroleum (TPH) in the soil even after incubation. TPH is lost at $10 \%$ level of contamination through consumption, utilization or breakdown of the cutting fluid contaminated soil into simple compound that are not harmful to the environment. There is possibility of fungus degrading TPH at a level of contamination as low as $1 \%$ engine oil concentration if the incubation period is elongated (Adenipekun and Isikhuemhen, 2008). The highest cation exchange capacity value was obtained at $10 \%$ level of contamination suggest that bioremediation best occurs at this level of contamination. A soil with cation exchange capacity of $10 \mathrm{meq} / 100 \mathrm{~g}$ and above as obtained at this level of contamination has the potential to be fertile when used for agricultural purposes (Rhoades et al., 1999). This CEC obtained in this study is also in consonant with the finding of Zebulun et al. (2011) in which CEC of $12.2 \mathrm{cmol} / \mathrm{kg}$ was obtained after incubating soil contaminated with anthracene with white rot fungus.

In conclusion, white rot fungus $P$. pulmonarius was effective in the remediation of both fresh and spent cutting fluid contaminated soil samples. The remediation of hydrocarbon based compounds by this fungus offers a better and more environmentally friendly technique if pro- perly and thoroughly explored over other chemical treatment methods.

\section{Recommendations}

This study therefore recommends that soil contaminated with cutting fluids can be treated with P.pulmonarius to reduce heavy metal contents and total petroleum hydrocarbon (TPH) to acceptable levels before final disposal to reduce the level of inherent environmental soil pollution. Such bioremediated contaminated soils can then be useful for agricultural purposes.

\section{REFERENCES}

Adenipekun CO (2008). Bioremediation of engine oil polluted soil by Pleurotus tuber regium Singer, a Nigerian White rot Fungus. Afr. J. Biotechnol. 7(1): 055- 058.

Adenipekun CO, Fasidi IO (2005). Bioremediation of oil-polluted soil by Lentinus subnudus, a Nigerian white-rot fungus. Afr. J. Biotechnol. 4(8): 796-798.

Adenipekun CO, Isikhuemhen OS (2008). Bioremediation of engine oil polluted soil by by a tropical white rot fungus, Lentinus squarrosulus Mont. (Singer). Pak J. Biol. Sci. 11(12): 1634 - 1637.

AOAC (2003). Association of Official Analytical Chemists. Method of Analysis, Washington D.C.

Atlas, RM (1995). Bioremediation. Chem. Eng. News, 73: 32-42.

Barr D, Aust SD (1994). Mechanisms white rot fungi use to degrade pollutants. Environ. Sci. Technol. 28: 79A-87A.

Benka-Coker MO, Ekundayo JAF (1995). The effect on an oil spill on some physic-chemical properties of a spill in the Niger-Delta area of Nigeria. Environ. Monit. Assess. 36:93-104.

Bio-wise (2001). A guide to biological treatment for metalworking fluids disposal. Published by Department of Trade Chemistry.

Bishnoi NR, Bishnoi K, Rajender K (2008). Biodegradation of polycyclic aromatic hydrocarbons by white rot fungus, Phanerochaete chrysosporium in sterile and unsterile soil. J. Sci. Ind. Res. 67: 538 542.

Croan SC (2000). Conversion of wood waste into value-added products by edible and medicinal (Fr.) P. Karst. Species (Agaricales S. I., Basidiomycetes).73-80.

Grady F (1985). Biodegradation. Its Measurement and Microbiological basis. Biotechnol. Bioeng. 27: 660-671.

Jonathan SG, Fasidi IO (2001). Effect of carbon, Nitrogen and Mineral sources on growth of Psathyrella atroumbonata (Pegler). A Nigerian mushroom. Food Chem. 72: 479-481.

Kalac P, Niznanska M, Berilaqua D, Staskova I(1996). Concentration of Mercury, Copper, Cadmium and Lead in fruiting bodies of edible Mushrooms in the vicinity of a mercury smelter and a copper smelter. Sci. Total Environ.1996: 177:251.

Kubatova A, Erbanová P, Eichlerová I, Homolka L, Nerud F, Sasek V (2001). PCB congener selective biodegradation by the white rot fungus Pleurotus ostreatus in contaminated soil. Chemosphere 43: 207- 215.

Lang E, Nerud F, Zadrazil, F (1998). Production of ligninolytic enzymes by Pleurotus spp and Dichomitus squalens in soil and lignocelluloses substrate as influenced by soil and lignocelluloses substrate as influenced by soil microorganisms FEMS Microbiol. Lett. 167:239244.

Lavrovsky V (2004). Microencapsulated enzyme systems. Enhanced oil recovery and bioremediation. Paper presented at the 2004 Calgary youth science fair. Retrieved on July 18,2012, fromhttp://www.physics.uwo.ca/teamcana/2003/vladic_lavrovsky_rep ort.pd

MAFF (1986). Ministry of Agriculture, Fisheries and Food. The analysis of agricultural materials, $3^{\text {rd }}$ ed. (method 32). pp. 98.

Onianwa PC, Essien, CA (1999). Petroleum hydrocarbon levels in sediments of stream and river within Ibadan city, Nigeria. Bull. Chem. 
Soc. Ethiopia, 13(1): 82-85.

Okparanma RN, Ayotamuno JM, Davis DD, Allagoa M (2005). Mycoremediation of polycyclic aromatic hydrocarbons (PAH) contaminated oil based drill cutting. Afr. J. Biotechnol. 10(26): 51495156.

Phillip JC, Atlas RM (2005). Bioremediation of contaminated soil and aquifers. In: Bioremediation: Applied Microbial Solution for RealWorld Environmental Clean Up.

Rhoades JDF, Chanduvi S, Lesch (1999). Soil salinity assessment: methods and interpretation of electrical conductivity measurements. FAO irrigation and drainage paper 57, Rome, Italy.

Siegel SA, Galun M, Siegel BZ (1990). Filamentous fungi as metal bioadsorbents. A review. Water Air Soil Pollut. 53: 335-334.
Sparks DL, Page, AL, Helmke, PA, Loeppert, RH, Soltanpour, PN, Tabatabai, MA, Johnson, CT, Summer ME (1996). Methods of soil analysis. Part 3: Chemical methods. Soil Science Society of America, Inc., American Society of Agronomy, Inc., Madison, WI.

Van der Gast CJ, Whiteley AS, Lilley A, Knowles CJ, Thompson IP (2002). Bacterial community structure and function in a metal working fluid. Environ. Microbiol. 5(6): 453- 61.

Zebulun OH, Isikhuemhen OS, Hilary I (2011). Decontamination of anthracene-polluted soil through white rot fungus- induced biodegradation. Environmentalist 31: 11-19. 